Article

\title{
The Choice of Spitzenkandidaten: A Comparative Analysis of the Europarties' Selection Procedures
}

\author{
Gert-Jan Put, Steven Van Hecke *, Corey Cunningham and Wouter Wolfs \\ Public Governance Institute, University of Leuven, 3000 Leuven, Belgium; E-Mails: gertjan.put@soc.kuleuven.be \\ (G.-J.P.), steven.vanhecke@soc.kuleuven.be (S.V.H.), corey.cunningham@europarl.europa.eu (C.C.), \\ wouter.wolfs@soc.kuleuven.be (W.W.) \\ * Corresponding author
}

Submitted: 5 October 2015 | Accepted: 23 December 2015 | Published: 29 February 2016

\begin{abstract}
The selection of leading candidates by the political families, the so-called Spitzenkandidaten, is relatively groundbreaking as it is the first form of political recruitment organized at the EU level. The literature on candidate selection procedures has so far concentrated on national parties and their procedures. To our knowledge the analytical model has not yet been applied at the EU level. This article will fill this gap by examining the selection procedures of Europarties, more particularly for their EC presidency candidates, a novelty of the 2014 European Parliament elections. Based on the analysis of the procedures applied within the European People's Party (EPP), the Party of European Socialists (PES), the Alliance of Liberals and Democrats for Europe Party (ALDE), the European Green Party (EGP), and the Party of the European Left (EL), one of the main findings of this article is that the procedures are largely copy-paste from the Europarties' internal procedures for selecting a president. This can largely be explained by the lack of time and experience their party elites had in the run-up to the 2014 elections. We therefore expect the Europarties to further professionalize their selection procedures and start the process earlier with more high profile politicians to stand as candidates in 2019.
\end{abstract}

\section{Keywords}

candidate selection; Europarties; European Commission; European elections

\section{Issue}

This article is part of the issue "How Different Were the European Elections of 2014?", edited by Wouter van der Brug, Katjana Gattermann and Claes de Vreese (University of Amsterdam, The Netherlands).

(C) 2016 by the authors; licensee Cogitatio (Lisbon, Portugal). This article is licensed under a Creative Commons Attribution 4.0 International License (CC BY).

\section{Introduction}

This article analyzes the Europarties' procedures for the selection of Spitzenkandidaten in the 2014 European Parliament (EP) elections. In the run-up to these elections, Europarties organized internal selections to determine their candidate for the presidency of the European Commission (EC). According to Sartori (1976, p. $64)$, the selection of candidates is the core activity that distinguishes parties from other political organizations. The 2014 elections can therefore be considered a landmark in the history of these supranational organizations: the more loosely organized European party federations have developed towards fully-fledged Europarties with their own internal decision-making procedures and the role they play in the EP elections. Moreover, it also meant a landmark for the EP elections as the Spitzenkandidaten made the 2014 campaign different from previous ones. For the very first time leading candidates with an official mandate from the Europarties campaigned and debated on behalf of and between their respective political families on a European Union (EU) wide scale. A vote in these EP elections therefore also became a choice for the next EC president (Hobolt, 2014).

For scholars of EU party politics, these selection 
procedures form an interesting and unique research opportunity. First, the nomination of Spitzenkandidaten is the first political recruitment process that fully takes place at the European level. Since there is no EUwide transnational constituency for the EP elections, candidate selection is traditionally organized by the national member parties while the members of the EC are appointed by their national governments (Wonka, 2007). Therefore, existing rules and mechanisms of elite recruitment at the EU level are still strongly influenced by national considerations and dominated by national political actors. Second, as it is the first time that Europarties organized these selection procedures, it would seem that their party elites started with a blank slate designing them. Self-evidently, these party organizations historically developed their own decision-making processes with, for instance, varying degrees of centralization and unanimity requirements. The main research question of this contribution is, then: to what extent is the design of novel candidate selection procedures of Spitzenkandidaten affected by existing intraparty decision-making procedures of Europarties?

This article aims to answer this question by analyzing the selection procedures for Spitzenkandidaten of five Europarties: the European People's Party (EPP), the Party of European Socialists (PES), the Alliance of Liberals and Democrats for Europe Party (ALDE), the European Green Party (EGP), and the Party of the European Left (EL). As such, we follow a comparative approach, focusing on five party cases operating in the same complex EU institutional environment, but with different decision-making procedures and possible outcomes. The nature, course and outcome of their procedures will be examined using the seminal theoretical framework on intra-party candidate selection developed by Hazan and Rahat (2010). Party scholars have developed these frameworks focusing on national parties' procedures. In this article these theories will be adapted to supranational party organizations that operate at the level of the EU.

Europarties' selection procedures for Spitzenkandidaten will be analyzed on the basis of party documents (statutes, regulations) and semi-structured interviews with members of the various party elites. Two waves of interviews took place: the first during the parties' campaigns and selection processes preceding the elections, and the second wave four months after the elections to make a hindsight evaluation of the applied selection procedures. Respondents were selected based on their involvement in the design and implementation of these candidate selection procedures (see Appendix).

The article is structured as follows. The next section first presents the central theoretical framework by Hazan and Rahat (2010) for the analysis of candidate selection procedures, and discusses its applicability to the case of the Europarties. Afterwards, we examine the Europarties' existing decision-making practices by re- viewing earlier literature on the internal organization of Europarties. With regard to other forms of political recruitment at the EU level, it was already mentioned that both the selection of MEP candidates as well as the appointment of European Commissioners is organized by national political actors. We argue that the selection of Spitzenkandidaten is relatively groundbreaking as it is the first form of political recruitment organized at the EU level. At the end of the section on political recruitment in the EU, we formulate a number of hypotheses on the expected differences in selection procedures among Europarties. Subsequently, the empirical section of this article analyzes and compares the Europarties' candidate selection procedures based on the analysis of party regulations and elite interviews. The conclusion puts the findings of this study in theoretical perspective.

\section{Trespassing the Secret Garden: A Theoretical Framework for Candidate Selection}

Party organizations bear the huge responsibility of nominating a set of competent and skilled candidates for parliamentary office. The quality of selected candidates directly determines the quality and strength of legislative assemblies and can, more generally, even affect the stability of representative democracies (Gallagher \& Marsh, 1988). Therefore, it is not surprising that party scholars have produced a great deal of literature on this crucial function of party organizations.

From a theoretical point of view, the study of intraparty candidate selection is interesting for a variety of reasons. First, the nature of selection procedures offers one of the best instances to observe the distribution of power within the parties. After all, "he who can make the nominations is the owner of the party" (Schattschneider, 1942). As a result, authors often analyze these intraparty procedures to determine the true party elite or dominant faction at a given moment in time (Harmel \& Janda, 1994).

Second, candidate selection is one of the main instruments for parties to enforce party discipline and control the legislative behavior of MPs (Bowler, Farrell, \& Katz, 1999; Hazan \& Rahat, 2006; Shomer, 2009). Since incumbent MPs rely on the party selectorate for reselection, they will be inclined to appease the party elite and toe the party line. This mechanism allows parties to reward loyalty or punish defection, for example by MPs who are building a personal reputation through personal vote-seeking behavior.

Third and lastly, the nature of candidate selection procedures has far-reaching consequences for crucial dimensions of representative democracy, such as intraparty competition, representativeness of candidate lists, participation levels of members and voters, and legislators' party responsiveness (Hazan \& Rahat, 2010). It has been demonstrated, for example, that 
some selection procedures lead to more representative candidate lists than others (Rahat, Hazan, \& Katz, 2008). Some authors even argue that more inclusive participation enhances competitiveness (Cross, 1996), but this has not always been empirically confirmed (Kenig, 2009).

The seminal framework for comparative analysis of candidate selection procedures has been developed by Hazan and Rahat (2010). Their model disentangles four dimensions of candidate selection: candidacy, party selectorate, decentralization, and voting/appointment systems. Candidacy refers to who is entitled to be selected by the party. Aspirant candidates do not only need to demonstrate their eligibility through party loyalty and affiliation, but are usually expected to fulfill additional requirements as well (Kenig, 2009, p. 440). The degree of party inclusiveness can be evaluated by analyzing restrictions on candidacies. On the inclusiveness pole of the candidacy continuum, all citizens are allowed to put forward their candidacy. On the more exclusive end, some additional requirements may be added apart from mere eligibility. Examples of additional requirements are the need to pay a fee, to gather a fixed number of signatures, or to gain the support of an exclusive intra-party elite (Kenig, 2009, p. 440).

The party selectorate refers to a body that selects candidates. Rahat and Hazan (2001) propose a selectorate continuum where, at the one extreme the selectorate is composed of only one person, and at the opposite extreme it is constituted by the entire electorate. In this way, the continuum ranges from most exclusive selectorates to most inclusive ones. In between both extremes, various bodies might have the task to select the party leader: the party elite, a parliamentary party group, a selected party agency, or party members.

The dimension of decentralization refers to the influence of regional or local party branches in the candidate selection process. Political parties might have highly centralized candidate selection procedures, where the national party level has full control over candidate nomination. The opposite scenario is when local party organizations dominate candidate selection without any form of national intervention.

The fourth and final dimension deals with the voting or appointment procedure. Voting procedures obviously refer to systems where party candidates are nominated on the basis of a vote by the selectorate. Within a voting system, representation control is reduced as the party has less control over the outcome of the vote, and thus upon the person that will be chosen as candidate-designate of the party. Appointment procedures, on the contrary, are said to enhance representation control: the party wields greater control over the decision of the person it will put forward to represent the party (Rahat \& Hazan, 2001, p. 307).

The literature on candidate selection procedures has so far concentrated on national parties and their procedures. Is it possible to apply this analytical framework, which has largely been developed for national party organizations, to Europarties? How should the four dimensions of Hazan and Rahat's model be translated to the context of EU level party organizations? Arguably, some differences between national and European party organizations should be taken into account before this framework can be applied to the EU level. The actual threshold for being a candidate to lead the EC, for instance, will for obvious reasons be considerably higher than for being nominated as a candidate for national (or European) legislative elections. While there is only one candidate for the Commission presidency for each political family, a party organization usually has a lot of candidates when it comes to national legislative elections. From this point of view, the Europarty candidate selection procedures for the EC presidency are more comparable to intraparty selection procedures for party president (or state president) rather than for members of parliament.

The selectorate dimension can be applied in a comparable way as with national candidate selection procedures. Decision-making could, in theory, be limited to selected and non-selected party agencies, or might involve more inclusive selectorates such as delegate conferences or even party members. However, Europarties do not have members in the same way as national party organizations do: membership to individual party members of the various national member parties is only given in an indirect way. In fact, national parties are first and foremost the members of Europarties, not individuals (Hertner, 2014). This makes it practically more difficult to address these individual members and organize very inclusive selection processes such as primaries.

Concerning decentralization, Europarties are not characterized by the same spatial organization as national parties, which often have various subnational party branches (regional, local) with varying degrees of importance and competences in decision-making. For Europarties, national member parties represent the party on the ground (Bardi, 2002), and the level of decentralization should be measured by the influence of these 'sub-European' party branches in the Europarties' candidate selection procedures. Finally, voting and appointment systems relate to how and on the basis of what type of majorities these parties take decisions. This dimension can be applied in a similar manner to European party organizations.

\section{Decision-Making Processes within Europarties}

Answering the main research question of this article not only requires a concise analytical framework for the analysis of candidate selection procedures, but also an in-depth knowledge of the existing decision-making practices of Europarties. Existing research on European party federations deals with their historical develop- 
ment, gradual enlargement towards new member parties and the relationship of these extra-parliamentary party organizations with the more important EP parliamentary groups. Only relatively recently, authors have shifted their focus to the comparative analysis of their organizational structures (Bardi, 2002; Gagatek, 2008; Hanley, 2008; Johansson \& Zervakis, 2002).

The reasons for this delayed attention may be related to the subordinate character of party federations compared to EP parliamentary groups, which already started playing an important role since the first EP elections in 1979. Compared to these institutionalized, integrated and well-organized party groups, European party federations were organizationally weak (Hix, 2001). Moreover, these federations only have indirect links with civil society through their member parties. This has long been an excuse for scholars to ignore the formal structure and organizational aspects of party federations.

Since their foundation in the 1970s, the four largest party federations have become more integrated organizations with increasingly transnational characteristics (Pridham \& Pridham, 1981; Van Hecke, 2010). The culmination point of this evolution is of course the new appointment system for the EC presidency, where every party federation organizes its own internal candidate selection process. In sum, Europarties are gaining relevance and the EU institutional model is becoming more partisan in nature, which makes the systematic examination of these party organizations more worthwhile. As their institutional environments are very similar, one could expect that the organizational structures of Europarties look very similar and evolve in a comparable manner. However, differing ideological backgrounds, organizational culture and decision-making practices may lead to differences in the organizational life of these transnational party families (Gagatek, 2008).

The available literature does not provide too many leads on the relation between ideological party family and organizational nature. In their review of party family typologies, Mair and Mudde (1998) disentangle four criteria by which party families could be categorized. While it was briefly mentioned that parties could also be compared in terms of their organization structures, their criteria only refer to the origin, policy and ideology, name, and transnational membership. In his classic work on the organization of political parties, Duverger (1954) was the first to argue that ideological party groups differ from each other in terms of their organizational nature. More specifically, socialist and social democratic parties would be more inclined to adopt centralized structures than their Christian democratic counterparts, who are known to give greater leeway for the existence of internal factions (Gagatek, 2008).

Based on Duverger's longstanding claim, we expect transnational party federations, who organize themselves according to party families or familles spirituelles
(Von Beyme, 1985), to have different traditions in terms of their organizational nature and decision-making practices. The question, then, is whether these differences also become apparent in the nature of Europarties' candidate selection procedures. In the remainder of this section, these organizational differences will be discussed based on an examination of Europarties' decision-making procedures. Specifically, we examine to what extent these procedures could be labeled as transnational or intergovernmental. A suitable indicator to answer this question would be the applied majority and voting systems. Analogous to decision-making in the EU institutional model, some intraparty decisions might be taken on the basis of simple, absolute or qualified majorities, while others require unanimity.

While Hix and Lord (1997) argue that parties usually take decisions based on general consensus, organization practice reveals substantial differences in voting procedures. The PES seems to have a unanimity tradition in decision-making (Gagatek, 2008). Only if general consensus seems impossible, PES will start working with qualified majorities to take political decisions. Additionally, if member parties had substantial formal reservations with regard to the outcome, the possibility to 'opt-out' of the decision could be applied, which was frequently used in all sorts of manifestos and political declarations (Hix \& Lesse, 2002). According to Gagatek (2008), the opting-out procedure is still incorporated in PES statutes, but has recently not been used very frequently.

Analogous to their Socialist counterpart, the Liberal party federation also has the culture of working towards general consensus in decision-making. The ALDE has been very preoccupied with organizational reforms to achieve greater party cohesion and consolidation (Sandstrom, 2001). When ELDR, the forerunner of ALDE, was founded in 1976, it could immediately be called a federative party where decisions were taken with a qualified majority, and from 1991 onwards even with only a simple majority. However, there has always been a strong consensus culture in order to keep the highly diverse set of Liberal member parties aboard (Smith, 2014).

The European Greens, united by the EGP, are a third example of a strong unanimity based party model (Van De Walle, 2001). This party federation seems to work with less centralized party organs, but at the same time applies very strict qualified majority principles and, preferably, unanimous decision-making (Bardi, 2002). Based on the existing theories and literature on Green political parties, one might expect that the EGP would actually be the organizational outlier among Europarties. Green parties usually seek to establish grass-roots party organizations with principles of basic democracy (MüllerRommel, 1989). But while some characteristics of this party type are present in EGP (e.g. rotation principle, no cumulation of offices), Van De Walle (2001) argues that the influence of the European institutional environment 
is actually larger than the influence of typical ecological party culture. Moreover, the Green parties' antibureaucratic and decentralized approach has made them reluctant to give up national sovereignty in order to become more transnationalized (Dietz, 2000).

The same applies to the EL. The party subscribes to the rotation principle, emphasizes its popular basis, and brings gender equality into practice $(50 \%$ share of women in all organs), but whereas (former) communist parties are traditionally highly centralized, their European party lacks integration (Hudson, 2012). One could even call the EL 'intergovernmental' (Hanley, 2008, p. 147), as national parties remain sovereign. In terms of voting, every member party is equal, irrespective of its size at the national level or its number of MEPs.

Of the five European party federations under consideration, the EPP is the actual outlier in terms of organizational characteristics. Compared to the other Europarties, the transnational character of the federation with the largest EP party group is considerably more outspoken. As early as the 1980s, the EPP identified the unanimity rule as the main factor hindering transnational development. Their statutes do not state anything about unanimity requirements, which points to a more integrated party structure compared to its competitors. Additionally, the EPP does not allow for opting-out of decision-making by any of the member parties or party actors (Gagatek, 2008).

A potential explanation for these differences in decision-making is the degree of intraparty homogeneity at the time of the parties' foundation. At first, EPP consisted of traditional, pro-European Christian democratic parties and had a considerably easier time coming to agreements on electoral manifestos compared to its competitors. There was a strong convergence in the way these parties thought of political integration in Europe, which directly influenced their ideas on further party integration (Pridham \& Pridham, 1981). Even after the enlargement that brought on board more conservative member parties, the party continued that tradition and applied more integrative voting procedures.

The Liberal and Socialist party federations had considerably less internal cohesion at the start, which translated into giving greater importance to the unanimity principle. The Liberal party federation had been struggling to overcome internal dissent as early as the 1970s (Sandstrom, 2001). The CSPEC, forerunner of the $\mathrm{PES}$, had considerably more difficulties in agreeing on electoral manifestos than the EPP (Gagatek, 2008). Finally, while it is often claimed that the Green party federation did not develop consolidated party structures compared to other Europarties (Bardi, 1994; Bardi, 1996; Jansen, 1996), they actually did succeed in building a more integrative and transnational party organization (Dietz, 2000). The strong heterogeneity in policy preferences of their member parties, however, continues to hinder decision-making on the basis of majority principles rather than unanimity. The latter also applies to the EL, a party that is characterized by a wide range of opinions and attitudes (Hanley, 2008).

This paper examines the extent to which the Europarties' new candidate selection procedures-designed for the selection of EC presidency candidates-are affected by these existing decision-making practices. At this point, two elements required to answer the main research question have been discussed: the analytical framework on candidate selection, and Europarties' organizational practices. A combination of these two building blocks allows us to formulate a number of testable hypotheses for each of the candidate selection dimensions. In terms of candidacy, the reviewed literature does not give any reason to expect substantial differences between the Europarties:

H1. The candidacy requirements of Europarties do not significantly differ from one another.

With regard to the inclusiveness of the selectorate, we already mentioned that green parties generally have a stronger tendency to apply democratic internal procedures than other party families. Therefore, we hypothesize that:

H2. The selectorate of the EGP will be more inclusive than the selectorates in the other Europarties' selection procedures.

The literature review revealed that the green party federation also stands out in terms of intraparty decentralization, in the sense that their party organs are less centralized compared to the other Europarties. As a result:

$\mathrm{H} 3$. The candidate selection procedure of the EGP will be more decentralized than the other

Europarties' procedures.

Finally, the voting or appointment procedures of Europarties have received the largest amount of research attention. For this fourth dimension, the literature review shows that the EPP is the deviant case compared to the other Europarties, as they apply the unanimity rule considerably less in intra-party decision-making. Indeed, while the EPP has a strong tradition of majoritarian voting procedures, the other Europarties are strongly oriented towards decision-making by consensus:

$\mathrm{H} 4$. While the candidate selection procedure of the EPP uses a voting procedure, the other Europarties apply appointment procedures.

\section{The Europarties' Candidate Selection Procedures for Spitzenkandidaten}

Although the idea that Europarties should present their candidates for the EC presidency dates back to at least 
2008 (Gagatek, 2009; Hix, 2008, pp. 155-163), the first time it was applied on a large scale was in the run-up to the EP elections of May 2014. In other words, Europarties engaged in nominating their own candidate through different selection procedures.

In its resolution of November 22, 2012, the European Parliament urged the Europarties to nominate candidates for the EC presidency and stressed that they should play a leading role in the EU electoral campaign (European Parliament, 2012). In March 2013, the EC also announced its recommendation for Europarties to nominate candidates. This was part of the Commission's strategy to get citizens more involved in EU decision-making and to increase the visibility and personal character of European elections. Designing candidate selection procedures which are democratic, for example, would raise the legitimacy of European institutions in general, and of Europarties in particular (European Commission, 2013). Indeed, some authors have argued that increasing intraparty democracy would raise citizens' levels of trust in political parties (Leduc, 2001; Scarrow, Webb, \& Farrell, 2000).

The Europarties were asked to make known which candidate they supported for the presidency, and national member parties were expected to inform voters about that candidate during the campaign. Survey research shows that a majority of respondents would be more inclined to vote in European elections if parties proposed a candidate for the function of European Commission President (European Commission, 2013).

As it was the first time that Europarties organized candidate selection, this was a rather unique and interesting research opportunity. Europarties started from a blank slate, and were free to design their selection procedure of choice. However, literature states that the decision to choose a particular procedure is determined by normative and institutional factors, such as the electoral system, legal requirements, and territorial divisions (Lundell, 2004; Scarrow et al., 2000; Shomer, 2014). But what is even more important in this context is the very specific organizational nature of parties at the EU level. Europarties are federated organizations: they consist of various separate member parties at the national level, amalgamated into European party organizations. Each national member party has its own internal rules, including rules with regard to the selection of candidates for the European Parliament. The applied procedures by the different Europarties will be explained in detail in this section.

\subsection{European People's Party (EPP)}

Historically, the European People's Party (EPP) emerged from "diverse forms of cooperation that had long existed among Christian democrats in Western Europe" and was officially founded in 1976 in the run up to the first European Parliament elections of 1979 (Hanley, 2008;
Jansen \& Van Hecke, 2011, p. 3). Although initially established by Christian democratic parties, the EPP later included conservative and center-right parties. Since 1999 it has the largest group in the European Parliament and it also holds major positions in the EC and the European Council, including the presidency.

The EPP decided on its candidate selection procedure during the Meise summit in December 2013. On this occasion, the party drew up a timeline for the selection of an EPP candidate that would best represent the party's values while having strong prospects of reaching a wide consensus in the European Council (which had to propose a candidate to the EP).

Concerning the candidacy dimension, the EPP stipulated that for a candidate to be nominated, he/she has to be affiliated to and supported by a national member party. Moreover, candidates need the endorsement of a maximum of two member parties from two EU countries other than the country of origin. On top of that, only presidents and secretary generals of ordinary member parties are entitled to nominate and/or endorse a candidate (European People's Party, 2014). The support of three parties was deliberately chosen as to avoid a race between the candidates to have the support of as many member parties as possible, like the ALDE for instance (L. Vandeputte, personal communication, November 14, 2014). The EPP equally wanted to avoid one candidate, since then it would become clear where he/she lacks support, as was the case with the PES and British Labour, for instance (K. Sasmatzoglou, personal communication, October 9, 2014).

By the closure of the candidate submission process, two candidates had submitted their candidacy: JeanClaude Juncker and Michel Barnier. The candidacy of Jean-Claude Juncker, former prime minister of Luxembourg as well as the Eurogroup, was backed by his own Christian Social People's party (CSV), the German CDU and the Greek Nea Demokratia. In addition, Michel Barnier, the incumbent European commissioner for internal market and services, received the support of his home party UMP, and the endorsement of the Hungarian Fidesz and the Slovenian NSi member parties. As a next step in the procedure, the two candidacies were reviewed and validated during the EPP Political Assembly, which was part of the overall program of the EPP Electoral Congress.

Candidacies were subjected to a delegates' vote during the EPP Electoral Congress. The candidate that received the absolute majority of valid votes would be declared elected. Abstentions were not considered valid votes. The final result of 828 delegates with voting rights was as follows: from the 627 votes cast, 382 votes went to Juncker (61\%) and 245 went in favor of Barnier (39\%) (Cerulus, 2014). Juncker greatly benefitted from the German delegation led by Angela Merkel, giving him the full backing of their total of 101 votes. Barnier, on the other hand, led a very active internal 
campaign to mobilize the votes of those delegates that appeared to be disenchanted with the dominance of the German Christian Democrats within the EPP.

The list of persons holding voting rights during the EPP Political Assembly is relatively extensive. Among these 828 EPP delegates, which represent the selectorate in the selection procedure, are the members of the EPP presidency, presidents and delegates of member parties and associations, heads of state and government of EU member states, and presidents of other European institutions (e.g. European Council, Council of Europe, and Committee of the Regions) that are affiliated with national member parties. The EPP's selectorate falls into the category of selected party agencies that usually take the form of conventions, conferences, or assemblies (Kenig, 2009, p. 436). The size of this category of selectorates typically ranges from a few hundred to sometimes over a thousand delegates selecting candidates or party leaders.

\subsection{Party of European Socialists (PES)}

The PES is the European level political family that assembles the Socialist, Social Democratic, and Labour parties of the EU under one umbrella. At the time of the selection, there were 33 full member parties spread across all 28 EU Member States and Norway. The PES also included 5 full member organizations (e.g. the PES Women), 12 associate and 10 observer parties. In recent decades, the PES has been the main rival of the EPP in the wider European political landscape. The $\mathrm{PES}$ also enjoys a strong representation in various EU institutions.

Already in 2010, the PES Council took the unanimous decision to set up a democratic and transparent process for designating the PES candidate for the European Commission Presidency (Party of European Socialists, 2010). A special 'Working Group Common Candidate 2014' was set up to this end (M. Laffeber, personal communication, September 15, 2014). During the 2009 elections, PES lacked a strong figurehead, which was in stark contrast to the rivaling EPP with Barroso as the lead candidate during the election campaign. The early adoption of candidate selection procedures for the 2014 elections demonstrated the PES' willingness to increase the party's visibility through the personalization of EU politics.

To stand as a legitimate candidate, PES formulated the following nomination criteria: nomination by a PES full member party or organization and support of $15 \%$ of PES full member parties or organizations, including their own party. Furthermore, a member party can only support one potential candidate. Given that the PES was composed of 32 full member parties within the EU and 5 full member organizations, a candidate had to come up with the support of a minimum of 6 parties or organizations in order to reach the $15 \%$ stipulated, i.e. one nominating her/him with 5 others supporting the nomination.

After the candidacy submission deadline, the PES presidency convened to check and validate the candidacies in order to draft a public list of potential candidates (PES, 2013). On this occasion, an electoral committee made up of representatives for each of the prospective candidates was also established in order to guarantee fairness. Because of the high candidacy requirements, Martin Schulz, incumbent president of the EP and member of the German SPD, emerged as the sole candidate for the PES. He obtained the support of 22 of the 32 PES member parties (Mahony, 2013), which made it very difficult for potential opponents to meet the nomination criteria. Once the nomination process was over, each member party and organization organized internal decision-making procedures to either support or reject Schulz' potential designation as the common PES candidate. To consolidate this vote at the European level, a weighting of the votes took place for each full member party and organization.

To conclude the overall process, the PES convened an Electoral Congress to ratify its candidate and adopt the party's common manifesto for a pan-EU campaign. During this congress where 405 delegates were eligible to cast their vote, Martin Schulz was confirmed as PES common candidate with 368 voting in his favor, 2 opposing and 34 abstentions (from, among others, the British Labour party).

\subsection{Alliance of Liberals and Democrats for Europe Party (ALDE)}

In the run-up to the 2014 European elections, ALDE was composed of 57 member parties. The liberal Europarty is traditionally considered the third largest group in the European Parliament. The relatively small chance of beating EPP or PES in numbers did not stop ALDE from launching its own candidate selection procedure for the EC presidency. In this procedure, all delegates could vote, unlike the election of the ALDE president. Delegates that were not present could vote online in advance. Candidates had to be formally nominated by at least two member parties from more than one member state or by $20 \%$ of ALDE Party Congress voting delegates (Alliance of Liberals and Democrats for Europe Party, 2013a). Surprisingly, candidates did not need the support of their own party (J. MorozaRasmussen, personal communication, November 4, 2014). During the nomination process, two candidates came forward: the incumbent Economic and Monetary Affairs Commissioner Olli Rehn, supported by 14mostly Nordic-member parties, and former Belgian Prime Minister and ALDE EP Group leader Guy Verhofstadt, nominated by the liberal parties of the Benelux (ALDE, 2013b; Cerulus, 2013). This is a consequence of the intra-party divisions that characterize the liberal 
party: the ALDE group is a cooperation of two separate Europarties - the European Democratic Party (EDP) and the Liberals-and has the widest range of policy positions among its member parties (McElroy \& Benoit, 2011, pp. 162-164). To avoid an open conflict between the different factions-the EDP threatened to leave the EP group if Olli Rehn would become the ALDE candidate-two mediators were appointed: Dutch prime minister Mark Rutte and Christian Lindner of the German FDP. They managed to make both nominees come to an agreement: Verhofstadt would be the ALDE candidate for the EC presidency and Rehn for one of the other senior positions in the EU (ALDE, 2014).

As a result, it was no longer necessary to organize a competitive procedure to determine the ALDE candidate. Participants at the ALDE Electoral Congress could simply approve or disapprove the agreement. The selectorate consisted of 32 member party delegations each entitled to a number of votes depending on the number of seats their party has in its national parliament. Of the 388 delegates, 245 approved the compromise in Verhofstadt's favor (79.3\%), 44 disapproved (14.2\%), and 20 delegates abstained (6.5\%).

\subsection{The European Green Party (EGP)}

The EGP is a pan-European party bringing together Green parties from across EU member states as well as non-EU countries. The candidate selection procedure proposed by the EGP Committee was adopted by the EGP Council composed of all Green member parties. According to this procedure, any European Green politician with the ambition to run as the leading EGP candidate needs to be nominated by his/her national party and receive the support from at least four to a maximum of eight of the 33 EGP member parties (European Green Party, 2013). Moreover, all EU member parties have the right to exclusively support one candidate. After endorsements from the EGP member parties, four nominees (i.e. José Bové, Ska Keller, Rebecca Harms, and Monica Frassoni) were confirmed as EGP contenders.

Afterwards, these four contenders participated in an online open primary election. This first of its kind online 'Green Primary' increased the visibility of the EGP giving it an upbeat image while capturing the public's interest with its e-democracy project (J. Cremers, personal communication, September 12, 2014). A central priority of the EGP throughout this campaign was to emphasize the importance of more inclusive and participatory decision-making in the EU. All EU citizens, EGP supporters and sympathizers, were invited to take part in this online voting exercise, with the end goal of selecting two final figureheads to lead the EGP campaign.

The reasons for selecting two lead candidates are twofold. First, this stems from the EGP's conviction that leadership should be shared by two or more persons and not narrowed down to one person alone.
Secondly, the party firmly believes that both male and female should be represented in power and decisionmaking structures. This online selection procedure also reflects other EGP values: democracy, participation and inclusiveness, but also a high level of accessibility enabling as many people as possible to become involved. The EGP also opens the way to participation in the online voting procedure for younger citizens (i.e. as early as the age of 16). A total of 22,676 persons from all Member States voted, which led to the following results: 11,791 votes for Ska Keller; 11,726 for José Bové; 8,170 for Rebecca Harms and 5,851 for Monica Frassoni. As a result, Keller and Bové formed the duo to lead the Greens through the ins and outs of the 2014 EP elections.

\subsection{Party of European Left (EL)}

The EL was founded in 2004, in the run-up to the 2014 European Parliament elections. It has left-wing, (former) communist and socialist parties from various European countries as its members. Unlike the EPP and the PES, and much more so than ALDE and the EGP, the party suffers from geographical and electoral imbalances. Most of its member parties have no or little representation in a national parliament, except for the German Die Linke and the Greek Syriza (Coalition of the Radical Left). Moreover, it is much smaller than the other Europarties. Therefore the opportunity was taken to choose its own Spitzenkandidat in order to present the EL to a wider audience. The decision was made by the Council of Chairpersons, the main decision-making body, at its meeting in Madrid in October 2013. Alexis Tsipras, president of Syriza and vice-president of EL, was the only candidate. After being confirmed by the Council-not unanimously but by consensus-he was presented to the Congress in December 2013. Every member party had 12 delegates; 164 delegates took part in the vote. $84.15 \%$ voted in favor, $7.32 \%$ against, and $8.54 \%$ abstained (European Left, 2013). The main point of discussion was clearly not Tsipras but whether his candidacy implicitly legitimized the EU's political and institutional set-up that the EL strongly criticizes.

\section{A Comparison of Europarties' Selection Procedures}

This section highlights the similarities and differences between the various candidate selection procedures applied by Europarties in nominating candidates for Commission Presidency. More specifically, we analyze the four dimensions of candidate selection discussed earlier in the theoretical section of this article. Table 1 facilitates the comparison of procedures by summarizing the most important characteristics for each candidate selection dimension. This comparison allows us to confirm or reject the four hypotheses formulated earlier based on the Europarties' decision-making procedures and practices. 
Table 1. Comparison of Europarties' Candidate Selection Procedures: Analytical Dimensions and Outcome. Source: Party statutes, internal regulations and interviews (see Appendix).

\begin{tabular}{|c|c|c|c|c|c|}
\hline & EPP & PES & ALDE & EGP & EL \\
\hline Candidacy & $\begin{array}{l}\text { Support by } \\
\text { national member } \\
\text { party + max. two } \\
\text { foreign member } \\
\text { parties }\end{array}$ & $\begin{array}{l}\text { Support by } 15 \% \text { of } \\
\text { full member } \\
\text { parties (incl. own } \\
\text { party or other } \\
\text { party from own } \\
\text { country) }\end{array}$ & $\begin{array}{l}\text { Support by at least } \\
\text { two member } \\
\text { parties (from } \\
\text { different countries) } \\
\text { or } 20 \% \text { of congress } \\
\text { delegates }\end{array}$ & $\begin{array}{l}\text { Support by at least } \\
\text { four and max. eight } \\
\text { member parties }\end{array}$ & $\begin{array}{l}\text { Support by } \\
\text { national party } \\
\text { president and the } \\
\text { Council of } \\
\text { Chairpersons }\end{array}$ \\
\hline Selectorate & $\begin{array}{l}828 \text { EPP delegates } \\
\text { at electoral } \\
\text { congress }\end{array}$ & $\begin{array}{l}405 \text { PES delegates } \\
\text { at electoral } \\
\text { congress }\end{array}$ & $\begin{array}{l}388 \text { ALDE delegates } \\
\text { at electoral } \\
\text { congress }\end{array}$ & $\begin{array}{l}\text { EU citizens above } \\
\text { the age of } 16\end{array}$ & $\begin{array}{l}164 \text { EL delegates at } \\
\text { electoral congress }\end{array}$ \\
\hline Decentralization & $\begin{array}{l}\text { Number of votes } \\
\text { for member } \\
\text { parties: three }+ \\
\text { number depending } \\
\text { on result in last } \\
\text { European election }\end{array}$ & $\begin{array}{l}\text { Number of votes } \\
\text { for member parties } \\
\text { based on } \\
\text { combination of } \\
\text { party strength in } \\
\text { national } \\
\text { parliament, } \\
\text { European } \\
\text { parliament and } \\
\text { country size }\end{array}$ & $\begin{array}{l}\text { Number of votes } \\
\text { for member party } \\
\text { delegations } \\
\text { depends on party } \\
\text { strength in national } \\
\text { parliaments }\end{array}$ & $\begin{array}{l}\text { One man one } \\
\text { vote-no weights } \\
\text { for member parties } \\
\text { or countries }\end{array}$ & $\begin{array}{l}12 \text { votes each } \\
\text { member party }\end{array}$ \\
\hline $\begin{array}{l}\text { Voting or appointment } \\
\text { procedures }\end{array}$ & $\begin{array}{l}\text { Absolute majority } \\
\text { of valid votes by } \\
\text { EPP delegates } \\
\text { (abstentions not } \\
\text { valid) }\end{array}$ & $\begin{array}{l}\text { Qualified majority } \\
\text { of valid votes by } \\
\text { PES delegates }\end{array}$ & $\begin{array}{l}\text { Absolute majority } \\
\text { of valid votes by } \\
\text { ALDE delegates (in } \\
\text { two rounds if } \\
\text { necessary) }\end{array}$ & $\begin{array}{l}\text { Relative majority of } \\
\text { selectorate; two } \\
\text { winning candidates } \\
\text { cannot be of same } \\
\text { sex or member } \\
\text { state }\end{array}$ & $\begin{array}{l}\text { Voting procedure, } \\
\text { but not stipulated }\end{array}$ \\
\hline Outcome & $\begin{array}{l}\text { Jean-Claude } \\
\text { Juncker } \\
\text { Michel Barnier } \\
\text { Valdis } \\
\text { Dombrovskis* }\end{array}$ & Martin Schulz & $\begin{array}{l}\text { Guy Verhofstadt } \\
\text { Olli Rehn* }\end{array}$ & $\begin{array}{l}\text { José Bové } \\
\text { Ska Keller } \\
\text { Monica Frassoni } \\
\text { Rebecca Harms }\end{array}$ & Alexis Tsipras \\
\hline
\end{tabular}

Note: Candidates in bold are the selected Spitzenkandidaten. Candidates with an asterisk withdrew their candidacy before selection took place.

First, candidacy requirements do not show great variation among the various Europarties' selection procedures. In general, all parties require their nominees to be party members with some additional requirements (Hazan \& Rahat, 2010). More specifically, apart from affiliation to one's own national member party, nominees are also required to gain the support of a defined set of other member parties and organizations. The EL is the outlier here, as the candidate needs to be put forward by its national party president. Among the other Europarties, there are, however, differences in the degree of strictness in their additional 'transnational' requirements. The PES clearly applies the strictest procedure, where nominees are expected to gather the support of no less than $15 \%$ of the other member parties. This resulted in a candidate selection process lacking intra-party competition, as only Schulz succeeded in gaining sufficient endorsement within the PES party organization. In addition, formal candidacy criteria do not mention any requirements with regard to candidates' personal qualities or experience. In practice, however, the various party nominees can be considered seasoned heavyweight politicians, with some of them having a background as former prime minis- ters. In sum, while some variation exists in terms of the required member parties' support, the candidacy requirements do not differ significantly from one another, which confirms the first hypothesis, with the EL as an exception.

Second, with regard to the nature of the selectorate, the EGP clearly stands out when compared to the other Europarties. This confirms the second hypothesis, which stated that the EGP selectorate would be more inclusive compared with the other selectorates. Indeed, the Greens organized an extremely inclusive selection procedure where all voters and citizens older than 16 were eligible to participate online. Self-evidently, this primary election is located at the extreme inclusive end of the inclusiveness-exclusiveness continuum. The other four Europarties each organized party conferences to select the final candidate for EC presidency. These party agencies were composed of party delegates in the cases of PES, ALDE and EL, and additionally high-level intra-party officeholders in the case of EPP. In other words, selectorates of these four parties are situated towards the more exclusive end of the continuum when compared to the EGP procedure. The PES selectorate is probably even more exclusive than the ALDE, 
EPP and EL procedures, since the formal PES procedure requires nominees to be checked and validated first by the PES presidency before presenting candidates to the wider selectorate.

Third, the level of decentralization in Europarties' candidate selection processes has to be measured by the influence of national member parties. Analogous to the selectorate dimension, the EGP's selection procedure differs substantially in terms of decentralization. More specifically, the online primary election did not take into account any demographic balances, making it a comparatively more centralized candidate selection procedure than the ones organized by EL, PES, ALDE and EPP. Within EL every member party counts equally while the latter three parties take the members states' demographic weight in their delegate conferences into account. This makes the final step of the selection process fairly decentralized in nature. On the other hand, none of the analyzed candidate selection procedures allows for individual member parties to nominate EC presidency candidates unilaterally. As discussed earlier, candidacies always have to be supported by a number of member parties and organizations, which decreases the decentralized nature of candidate selection procedures. As a consequence, the results show that the third hypothesis should be rejected: the level of decentralization is substantially lower within the EGP compared to the other Europarties.

Fourth and lastly, not only the EPP but all five Europarties opted for voting procedures rather than appointment systems to nominate their candidates. By applying voting systems, the parties have deliberately chosen reduced representational control: there is no need for general consensus on the selected candidates among selectors (Hazan \& Rahat, 2010). Therefore our last hypothesis is rejected. It should be noted, however, that only within the EPP and the EGP voters had a clear choice between different candidates. All parties tried to create a balance between encouraging internal debate and sending a unified message to the outside world. Clearly, by having two candidates that almost split the whole Europarty, ALDE took the riskiest path but eventually opted for the safe road.

\section{Conclusion}

This article analyzed the selection procedures of Spitzenkandidaten in the 2014 European Parliament (EP) elections as designed and executed by the European People's Party (EPP), the Party of European Socialists (PES), the Alliance of Liberals and Democrats for Europe Party (ALDE), the European Green Party (EGP), and the Party of the European Left (EL). The choice of Spitzenkandidaten was a relatively groundbreaking process as it was the first form of political recruitment organized at the EU level. This made the 2014 EP elections different from previous ones, as these candidates organized a Europe-wide campaign and voters had the possibility to take the profile and the program of the EC presidency candidates-the choice for Spitzenkandidaten-into account when going to the polls.

All Europarties had to start from scratch, since there was no tradition to lean upon (J. MorozaRasmussen, personal communication, November 4, 2014). They had to invent something (J. Cremers, personal communication, September 12, 2014; L. Vandeputte, personal communication, November 14, 2014) so the easiest and least time consuming way to solve this problem was to copy-paste existing procedures, particularly the ones to elect a Europarty president, applying the same majority rule, the same delegates voting, etc. As a result, the novel candidate selection procedures for the selection of the EC presidency candidate were strongly inspired by already existing decision-making practices of Europarties.

Even though doubts exist as to whether the Spitzenkandidaten were able to reinforce the link between the EP elections and the EC president (Hobolt, 2014), Europarties embraced the new selection process as a means of strengthening their position at the EU level. This is not to say that the procedures cannot be improved (L. Vandeputte, personal communication, November 14, 2014). Europarties have to evaluate the process and the outcome. One has to bear in mind that the selection procedures were set up at a moment when the Europarties did not have any guarantees that the candidate of the largest party would actually become the head of the EC. Many government leaders considered the nomination of the EC president the prerogative of the European Council and remained skeptical of the entire process even after the European elections had already taken place. Only because the Europarties themselves had built up momentum around the Spitzenkandidaten process and the European Parliament had put pressure on the heads of state and government in the direct aftermath of the elections, EPP candidate Jean-Claude Juncker was nominated by the European Council and subsequently elected by the Parliament as the new EC president. This can explain why the procedures were put in place relatively late and in line with existing party practices.

Despite several shortcomings it is clear that the Spitzenkandidaten set a precedent for the 2019 elections (M. Laffeber, personal communication, September 15,2014$)$. On the $11^{\text {th }}$ of November 2015, the European Parliament adopted a text for the reform of the electoral law of the EU, which demonstrates that the Spitzenkandidaten process will become an indispensable aspect of the 2019 election campaign. The Parliament urges the Europarties to nominate their candidates for the EC presidency at least 12 weeks before the elections and to establish democratic and transparent procedures to select the candidates. Furthermore, it encourages the member states to facilitate the 
participation of the Europarties and their lead candidates in electoral campaigns and in the media (European Parliament, 2015). As a consequence, we expect that the Europarties will further professionalize their selection procedures and start the process earlier with more high profile politicians standing as candidates in order to maximize public and media attention. In this way, the 2014 EP elections might prove to be a game changer in the role played by Europarties and their influence on the inter-institutional balance within the EU.

\section{Acknowledgments}

The authors wish to thank the interviewees and anonymous reviewers for their suggestions. Gert-Jan Put and Wouter Wolfs gratefully acknowledge the FWOResearch Foundation Flanders for their support.

\section{Conflict of Interests}

The authors declare no conflict of interests.

\section{References}

Alliance of Liberals and Democrats for Europe. (2013a). Internal regulations of the ALDE party, AISBL. ALDE Party. Retrieved from http://www.aldeparty.eu/sites/ eldr/files/revised_draft_internal_rules_pula13.pdf

Alliance of Liberals and Democrats for Europe. (2013b). Olli Rehn Nomination Letter. Europe decides. Retrieved from http://europedecides.eu/wp-content/u ploads/2013/12/e73169f46e7585e657a892325ebfa bd8-1.pdf

Alliance of Liberals and Democrats for Europe. (2014). Olli Rehn and Guy Verhofstadt reach agreement on lead candidacy. ALDE Party. Retrieved from http://www.aldeparty.eu/en/news/olli-rehn-andguy-verhofstadt-reach-agreement-lead-candidacy

Bardi, L. (1994). Transnational party federations, European parliamentary party groups and the building of Europarties. In R. Katz \& P. Mair (Eds.), How parties organize (pp. 357-372). London: Sage.

Bardi, L. (1996). Transnational trends in European parties and the 1994 elections of the European Parliament. Party Politics, 2(1), 99-114.

Bardi, L. (2002). Parties and party systems in the European Union. In K. Luther \& F. Müller-Rommel (Eds.), Political parties in the New Europe: Political and analytical challenges, (pp. 293-322). Oxford: Oxford University Press.

Bowler, S., Farrell, D., \& Katz, R. (Eds.). (1999). Party discipline and parliamentary government. Columbus: Ohio State University.

Cerulus, L. (2013). Rehn in pole position to lead EU liberals in 2014 election campaign. EurActiv. Retrieved from http://www.euractiv.com/eu-elections-2014/ rehn-surpasses-verhofstadt-favou-news-532421
Cerulus, L. (2014). Juncker beats rival in centre-right race for EU presidency. EurActiv. Retrieved from http:// www.euractiv.com/sections/eu-elections-2014/junck er-beats-rival-centre-right-race-eu-presidency-300745

Cross, W. (1996). Direct election of Provincial party leaders in Canada, 1985-1995: The end of the leadership convention? Canadian Journal of Political Science, 29(2), 295-315.

Dietz, T. (2000). Similar but different? The European Greens compared to other transnational party federations in Europe. Party Politics, 6(2), 199-210.

Duverger, M. (1954). Political parties: Their organization and activity in the modern state. London: Methuen.

European Commission. (2013). 2014 European Parliament elections: Commission recommends that political parties nominate candidate for Commission President. European Union. Retrieved from http://euro pa.eu/rapid/press-release_IP-13-215_en.htm

European Green Party. (2013). Call for candidates for the green primaries. European Greens. Retrieved from http://europeangreens.eu/news/call-candidates-gre en-primary

European Left. (2013). Tsipras, nominated by the European Left, as the voice to denounce the policies of the Troika in the European Commission. European Left. Retrieved from http://www.european-left.org/ 4th-el-congress/tsipras-nominated-european-left-voi ce-denounce-policies-troika-european-commission

European Parliament (2012). Resolution on the elections to the European Parliament in 2014 (2012/2829(RS P)). European Parliament. Retrieved from http:// www.europarl.europa.eu/sides/getDoc.do?pubRef=//EP//NONSGML+TA+P7-TA-2012-0462+0+DOC+PDF $+\mathrm{VO} / / \mathrm{EN}$

European Parliament. (2015). Resolution of 11 November on the reform of the electoral law of the European Union (2015/2035(INL)). European Parliament. Retrieved from http://www.europarl.europa.eu/si des/getDoc.do?pubRef=-//EP//NONSGML+TA+P8TA-2015-0395+0+DOC+PDF+VO//EN

European People's Party. (2014). Voting regulation for the election of the EPP President and the election of the EPP candidate for president of the European commission adopted by the EPP political assembly. European People's Party. Retrieved from http://du blin2014.epp.eu/wp-content/uploads/2014/02/Vot ing-regulation-Dublin-2014-EN.pdf

Gagatek, W. (2008). Political parties at the European level. Their organization and activities: The case of the European People's Party and the Party of European Socialists. (Unpublished Doctoral Dissertation). European University Institute, Florence, Italy.

Gagatek, W. (2009). Campaigning in the European Parliament elections. In W. Gagatek (Ed.), The 2009 elections to the European Parliament: Country reports (pp. 13-19). Florence: European University Institute. 
Gallagher, M., \& Marsh, M. (Eds.). (1988). The secret garden of politics: Candidate selection in comparative perspective. London: Sage.

Hanley, D. (Ed.). (2008). Beyond the nation state: Parties in the era of European integration. Basingstoke: Palgrave Macmillan.

Harmel, R., \& Janda, K. (1994). An integrated theory of party goals and party change. Journal of Theoretical Politics, 6(3), 259-287.

Hazan, R., \& Rahat, G. (2006). The influence of candidate selection methods on legislatures and legislators: Theoretical propositions, methodological suggestions and empirical evidence. The Journal of Legislative Studies, 12(3-4), 366-385.

Hazan, R., \& Rahat, G. (2010). Democracy within parties: Candidate selection methods and their political consequences. Oxford: Oxford University Press.

Hertner, I. (2014). Running the show? Europarty members as election campaigners for the Party of European Socialists and the European Green Party. In E. Stetter, K. Duffek \& A. Skrzypek (Eds.), In the name of political union-Europarties on the rise (pp. 142153). Brussels: Foundation for European Progressive Studies.

Hix, S. (2001). Parties at the European level. In P. Webb, I. Holliday \& D. Farrell (Eds.), Political parties in advanced industrial societies (pp. 280-309). Oxford: Oxford University Press.

Hix, S. (2008). What's wrong with the European Union and how to fix it. Cambridge: Polity Press.

Hix, S., \& Lord, C. (Eds.). (1997). Political parties in the European Union. Houndmills: Macmillan.

Hix, S., \& Lesse, U. (2002). Shaping a vision: A history of the Party of European Socialists 1957-2002. Brussels: Party of European Socialists.

Hobolt, S. B. (2014). A vote for the President? The role of Spitzenkandidaten in the 2014 European Parliament elections. Journal of European Public Policy, 21(10), 1528-1540.

Hudson, K. (2012). The new European left. A socialism for the twenty-first century? Basingtoke: Palgrave Macmillan.

Jansen, T. (Ed.). (1996). Die Entstehung einer Europäischen Partei: Vorgeschichte, Gründung und Entwicklung der EVP. Bonn: Europa-Union Verlag.

Jansen, T., \& Van Hecke, S. (2011). At Europe's service: The origins and evolution of the European People's Party. Heidelberg: Springer/Centre for European Studies.

Johansson, K., \& Zervakis, P. (Eds.). (2002). European political parties between cooperation and integration. Baden-Baden: Nomos.

Kenig, O. (2009). Democratization of party leadership selection: Do wider selectorates produce more competitive contests? Electoral Studies, 28(2), 240-247.

Leduc, L. (2001). Democratizing party leadership selection. Party Politics, 7(3), 323-341.
Lundell, K. (2004). Determinants of candidate selection: The degree of centralization in comparative perspective. Party Politics, 10(1), 25-47.

Mahony, H. (2013). Schulz named 'candidate designate' for commission post. EUObserver.com. Retrieved from https://euobserver.com/political/122004

Mair, P., \& Mudde, C. (1998). The party family and its study. Annual Review of Political Science, 1(1), 211229.

McElroy, G., \& Benoit, K. (2011). Policy positioning in the European Parliament. European Union Politics, 13(1), 150-167.

Müller-Rommel, F. (Ed.). (1989). New politics in Western Europe: The rise and success of Green parties and alternative lists. Boulder: Westview.

Party of European Socialists. (2010). A democratic and transparent process for designating the PES candidate for the European Commission Presidency: Resolution adopted by the PES Council in Warsaw on 2 December 2012. Retrieved from http://d3n8a8pro 7vhmx.cloudfront.net/partyofeuropeansocialists/pag es/90/attachments/original/1394736921/adopted_p es_council_resolution_2_en.pdf?1394736921

Party of European Socialists. (2013). Selecting our common candidate for the 2014 European elections. Retrieved from http://cdn.knightlab.com/libs/timeline/ latest/embed/index.html?source=0AhuAdANoHnf2d G95QVF2b0Q3ZGQxV1VvQIVVMW9wYIE\&font=PTSe rif-PTSans\&maptype=toner\&lang=en\&height $=100 \% 2$ Owidth='100\%25'\%20height='100'\%20frameborder='0'

Pridham, G., \& Pridham, P. (Eds.). (1981). Transnational party co-operation and European integration: The process towards direct elections. London: Allen \& Unwin.

Rahat, G., \& Hazan, R. (2001). Candidate selection methods: An analytical framework. Party Politics, 7(3), 297-322.

Rahat, G., Hazan, R., \& Katz, R. (2008). Democracy and political parties: On the uneasy relationship between participation, competition and representation. Party Politics, 14(6), 663-683.

Sandstrom, C. (2001). Le parti européen des libéraux, democrats et réformateurs. De la coopération à I'intégration. In P. Delwit, E. Külahci \& C. Van de Walle (Eds.), Les fédérations européennes de partis: Organisation et influence (pp. 123-140). Brussels: ULB.

Sartori, G. (1976). Parties and party systems: A framework for analysis. Cambridge: Cambridge University Press.

Scarrow, S., Webb, P., \& Farrell, D. (2000). From social integration to electoral contestation: The changing distribution of power within political parties. In R. Dalton \& M. Wattenberg (Eds.), Parties without partisans: Political change in advanced industrial democracies (pp. 129-151). Oxford: Oxford University Press. Schattschneider, E. (Ed.). (1942). Party government. New 
York: Farrar and Rinehart.

Shomer, Y. (2009). Candidate selection procedures, seniority and vote-seeking. Comparative Political Studies, 42(7), 945-970.

Shomer, Y. (2014). What affects candidate selection processes? A cross-national examination. Party Politics, 20(4), 533-546.

Smith, J. (2014). Between ideology and pragmatism: Liberal party politics at the European level. Acta Politica, 49(1), 105-121.

Van de Walle, C. (2001). La fédération européenne des partis verts: Une organisation plutôt européenne qu'écologiste. In P. Delwit, E. Külahci \& C. Van de
Walle (Eds.), Les fédérations européennes de partis: Organisation et influence (pp. 141-154). Brussels: ULB.

Van Hecke, S. (2010). Do transnational party federations matter? (...Why should we care?). Journal of Contemporary European Research, 6(3), 395-411.

Von Beyme, K. (Ed.). (1985). Political parties in Western Democracies. Aldershot: Gower.

Wonka, A. (2007). Technocratic and independent? The appointment of European Commissioners and its policy implications. Journal of European Public Policy, 14(2), 169-189.

\section{About the Authors}

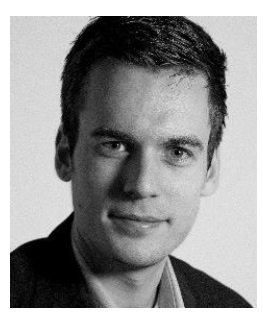

\section{Dr. Gert-Jan Put}

Gert-Jan Put is a researcher at the Research Foundation Flanders (FWO) affiliated to the KU Leuven Public Governance Institute. His research interests include candidate selection, legislative turnover and campaign spending. He obtained his PhD with a thesis on the geographical dimension of candidate selection, and has been published in Political Behavior, Electoral Studies and Acta Politica. He is also a visiting researcher at Tel-Aviv University.

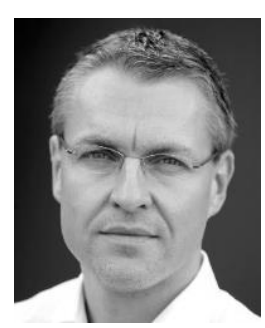

\section{Dr. Steven Van Hecke}

Steven Van Hecke is assistant professor at the Faculty of Social Sciences (KU Leuven) where he teaches Comparative and EU Politics. His research is mainly about Europarties and EU institutions. He has published in Acta Politica, Journal of Common Market Studies, Journal of European Public Policy, International Journal of Iberian Studies, and Journal of Contemporary European Research.

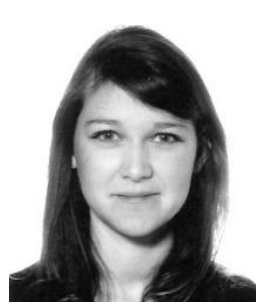

\section{Corey Cunningham}

Corey Cunningham obtained her Master's Degree in Translation and European Institutions from the Institut Libre Marie Haps in Brussels in 2012. Ms. Cunningham then pursued her academic curricula by enrolling herself for the Advanced Master in European Politics and Policies at the KU Leuven in 2013. Ms. Cunningham currently works as a Parliamentary assistant to Belgian Member of the European Parliament, Mr. Claude Rolin.

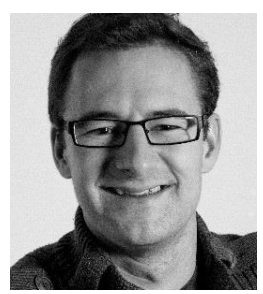

\section{Wouter Wolfs}

Wouter Wolfs is a researcher at the KU Leuven Public Governance Institute. He is preparing a PhD in political science on the finance regime of Europarties, European foundations, and political groups in the European Parliament. The focus of his research is on the impact of the EU regulatory framework and European subsidies on the development of the Europarties, and on the spending patterns and internal financial decision-making processes of the parties. 
Appendix. List of interviews undertaken in the framework of this manuscript

\begin{tabular}{llll}
\hline EPP & Kostas Sasmatzoglou & EPP Spokesperson & $09 / 10 / 2014$ \\
& Luc Vandeputte, & EPP Deputy Secretary General & $14 / 11 / 2014$ \\
PES & Marije Laffeber & PES Deputy Secretary General & $15 / 09 / 2014$ \\
& Alberto Bondesio Martinez & PES Assistant President, Secretary General and & $05 / 06 / 2014$ \\
& & Deputies Office & \\
\multirow{2}{*}{ ALDE } & Didrik de Schaetzen & ALDE Communication Officer ALDE Secretary & $04 / 06 / 2014$ \\
& Jacob Moroza-Rasmussen & General & $04 / 11 / 2014$ \\
EGP & Jacqueline Cremers & EGP Secretary General & $01 / 04 / 2014$ and \\
& & & $12 / 09 / 2014$ \\
EL & Maïté Mola & EL Vice President & $29 / 10 / 2014$ \\
\hline
\end{tabular}

Notes: Extra information about EL was asked but not yet received (15.12.2015). All interviews took place in Brussels. 